\title{
PELATIHAN TEKNIK PENULISAN KARYA ILMIAH UNTUK SISWA MAN 2 KOTA PROBOLINGGO
}

\author{
Indro Wicaksono*, Hermin Arista, Linda Kurnia S, Ary Analisa Rahma \\ Universitas Panca Marga Probolinggo \\ Corresponding Author * indrowicaksono@upm.ac.id
}

\begin{abstract}
The purpose of this training activity is to equip the students of MAN 2 Kota Probolinggo in producing good and interesting scientific work based on students' creative ideas, critical thinking, and innovative. The method of conducting this training includes three stages, the first stage of identifying students who have a desire to write scientific papers and carry out pretests. In the second stage, the delivery of material by means of lecture methods, discussions, and direct practice of the process of preparing scientific work. Next in stage 3 , is the student evaluation stage through posttest. The results of this scientific writing technique training include a noticeable improvement in writing techniques, field coverage, and the use of the internet as a reference for scientific work. Increased knowledge of students who are more creative in thinking to find ideas and ideas that can be used as topics to make scientific papers so that it becomes provision for purposes at a higher level.
\end{abstract}

Keywords: Writing, Writing Techniques, Scientific Papers

\begin{abstract}
Abstrak
Tujuan kegiatan pelatihan ini teknik penulisan karya ilmiah ini adalah untuk membekali para siswa MAN 2 Kota Probolinggo dalam menghasilkan karya ilmiah dengan baik dan menarik berdasarkan ide-ide kreatif, berpikir kritis, dan inovatif siswa. Metode pelaksanaan pelatihan ini meliputi tiga tahapan, tahap pertama melakukan identifikasi siswa yang memiliki keinginan untuk menulis karya ilmiah dan melaksanakan pretest. Pada tahap kedua, penyampaian materi dengan cara metode ceramah, diskusi, dan praktik langsung proses penyusunan karya ilmiah. Selanjutnya pada tahap 3 , adalah tahap evaluasi siswa melalui posttest. Hasil pelatihan teknik penulisan karya ilmiah ini meliputi adanya peningkatan nyata pada teknik menulis, cakupan bidang, dan penggunaan internet sebagai referensi karya ilmiah. Peningkatan pengetahuan siswa yang lebih kreatif dalam berpikir untuk menemukan ide dan gagasan yang dapat dijadikan sebagai topik untuk membuat tulisan karya ilmiah sehingga menjadi bekal untuk keperluan pada jenjang yang lebih tinggi.
\end{abstract}

Kata Kunci: Penulisan, Teknik Penulisan, Karya Ilmiah.

Copyright (c 2021, Indro Wicaksono, Hermin Arista, Linda Kurnia S, Ary Analisa Rahma. This is an open access article under the CC-BY NC-SA license http:// DOI 10.30656/ps2pm.v3i2.4127 


\section{PENDAHULUAN}

Semenjak diberikannya izin atas penyelenggaraan madrasah riset di MAN 2 Kota Probolinggo, telah menjadi suatu bentuk kewajiban bagi siswa di madrasah tersebut untuk mengenal tentang riset. Handani (2020) menjelaskan bahwa riset merupakan keinginan hasrat manusia yang dilaksanakan berdasarkan keilmuan tertentu. Yusuf (2017) menjelaskan juga bahwa riset merupakan suatu kegiatan yang sistemastis, objektif, dan logis serta terukur dengan mengendalikan variabel-variabel pada fenomena atau kejadian tertentu dalam menjawab masalah yang terjadi. Berdasarkan penjelasan di atas, sangatlah penting bahwa kegiatan riset yang dilaksanakan sejak dini akan mencetak lulusan madrasah yang kritis, kreatif, dan inovatif.

Dalam melaksanakan kegiatan riset, tentu perlu adanya laporan kegiatan secara ilmiah. Oleh sebab itu, teknik penulisan karya ilmiah menjadi dasar utama bagi peneliti dalam melaporkan kegiatan risetnya. Teknik menulis karya ilmiah inilah yang akan menjadi bahan untuk dapat dilatihkan kepada siswa madrasah. Untuk dapat menguasai teknik penulisan karya ilmiah siswa perlu mengetahui terlebih dahulu tentang makna paragraf. Semi (2007) dan Arifin (2008) menjelaskan bahwa paragraph merupakan susunan kalimat yang mengacu pada satu topik. Dalam setiap paragraf dapat terdiri dari beberapa kalimat yang terkait dengan satu topik tertentu.

Purnamasari, dkk (2020) dalam penelitiannya terkait penulisan karya tulis ilmiah telah berhasil menumbuhkan minat, semnagt, serta ide kreatif dan inovatif dari siswa untuk menghasilkan sebuah karya ilmiah yang sesuai dengan kaidah penulisan. Selain itu, Kurniawati, dkk (2018) juga menjelaskan pada penenlitiannya terkait pembuatan karya ilmiah remaja melalui pelatihan dan pendampingan telah meningkatnya minat siswa-siswa SMAN 6 dan MAN 2 Kota Madiun 
dalam menulis karya ilmiah dengan hasil penelitian atau kajian pemikiran, kemampuan menentukan masalah topik yang diinginkan, kemampuan menggunakan metode penulisan secara tepat. Peningkatan lainnya terjadi pada kemampuan siswa-siswa dalam mengoptimalkan penggunaan internet, dan kemampuan membuat karya ilmiah sesuai dengan metode penulisan ilmiah secara benar.

Berdasarkan hasil observasi yang dilakukan di MAN 2 Kota Proboliggo, teknik penulisan karya ilmiah belum diajarkan oleh guru di sekolah. Hal ini karena materi riset baru diajarkan di MAN 2 Kota Probolinggo di awal tahun ajaran 2021/2022 ini. Siswa masih diperkenalkan dengan hakikat dari karya ilmiah dan manfaat adanya karya ilmiah. Dengan begitu, sangatlah tepat apabila dilaksanakan pelatihan tentang karya ilmiah di MAN 2 Kota Probolinggo. Dengan adanya pelatihan ini akan mempercepat siswa-siswi madrasah dalam menghasilkan karya ilmiah sesuai dengan kaidah penulisan yang ilmiah yang benar dan menarik. Harapannya dalam mendukung madrasah dalam melaksanakan madrasah riset.

Seperti halnya pelatihan yang dilakukan oleh tim Pengmas yang dipimpin oleh Rossana Margaret Kadar Yanti (2017) yang dilaksanakan SMAN 9 Balikpapan memaparkan bahwa salah satu materi yang diberikan kepada siswa-siswi adalah struktur atau sistematika penulisan karya ilmiah yang terdiri dari judul, abstrak, pendahuluan, tujuan, metode, hasil dan pembahasan, serta kesimpulan. Selain itu, hal terpenting yang perlu diberikan kepada siswa adalah Orisinalitas karya ilmiah atau pencegahan plagiarisme juga harus dijaga karena ini berkenaan dengan kode etik penulisan ilmiah (Shadiqi, 2019).

LOKASI DAN PARTISIPAN KEGIATAN

Kegiatan pengabdian masyarakat ini dilakukan di MAN 2 
Kota Probolinggo Jln. MT Hariono

No. 163 kelurahan Mangunharjo

Kecamatan Mayangan Kota

Probolinggo pada bulan Oktober

2021. Peserta yang menjadi sasaran pada kegiatan ini adalah siswa-siswi MAN 2 Kota Probolinggo yang berjumlah 29 orang pada kelas X IPA 6.

\section{METODE PELAKSANAAN}

Pelaksanaan pengabdian masyakat ini menawarkan diadakannya pelatihan Teknik Penulisan Karya Ilmiah kepada siswasiswi MAN 2 Kota Probolinggo dengan metode pelaksanaanya:

1. Tahap pertama adalah tahap persiapan yakni dengan melakukan identifikasi siswa-siswi MAN 2 Kota Probolinggo yang memiliki keinginan untuk menulis karya ilmiah dan melaksananakan prestest.

2. Tahap kedua menggunakan metode ceramah dan diskusi, metode praktik langsung proses penyusunan karya ilmiah. Metode ceramah ini digunakan untuk menjelaskan tentang pentingnya ilmu mengenai teknik penulisan karya ilmiah bagi siswa siswi sekolah menengah, selain menambah wawasan ilmu tersebut akan memudahkan mereka jika suatu saat ada lomba atau tugas dari guru. Sedangkan metode praktik langsung proses penyusunan karya ilmiah sederhana yang bertujuan untuk memberikan kesempatan pada siswasiswi kelas X IPA 6 belajar secara langsung mengenai metode-metode dalam penyusunan karya ilmiah seperti perumusan judul, perumusan masalah, latar belakang masalah, metode pengambilan data dan sebagainya. Dengan konsep learning by doing maka pengetahuan dan keterampilan akan mendapatkan hasil secara maksimal.

3. Tahap ketiga adalah evaluasi. Kegiatan evaluasi ini bertujuan untuk mengetahui apakah kegiatan ini sudah sesuai atau tidak. Evaluasi ini dilakukan dengan menyebar angket tanggapan peserta pelatihan terhadap proses kegiatan. Indikator evaluasi ini adalah untuk mengukur kemampuan 
peserta dalam menyerap informasi dalam hal pengetahuan dan keterampilan penyusunan karya ilmiah melalui posttest.

\section{HASIL DAN PEMBAHASAN}

Sebelum

melaksanakan

pelatihan teknik penulisan karya ilmiah, dilakukan pre-test terlebih dahulu. Siswa dibimbing untuk mengisi kuesioner yang sudah diunggah pada google form. Pre-test yang diberikan sebanyak 10 soal dengan skala likert 1 sampai 5 . Pernyataan kuesioner tersebut dapat dilihat pada Tabel 1.

Tabel 1. Kuesioner Kegiatan Penulisan Karya Ilmiah

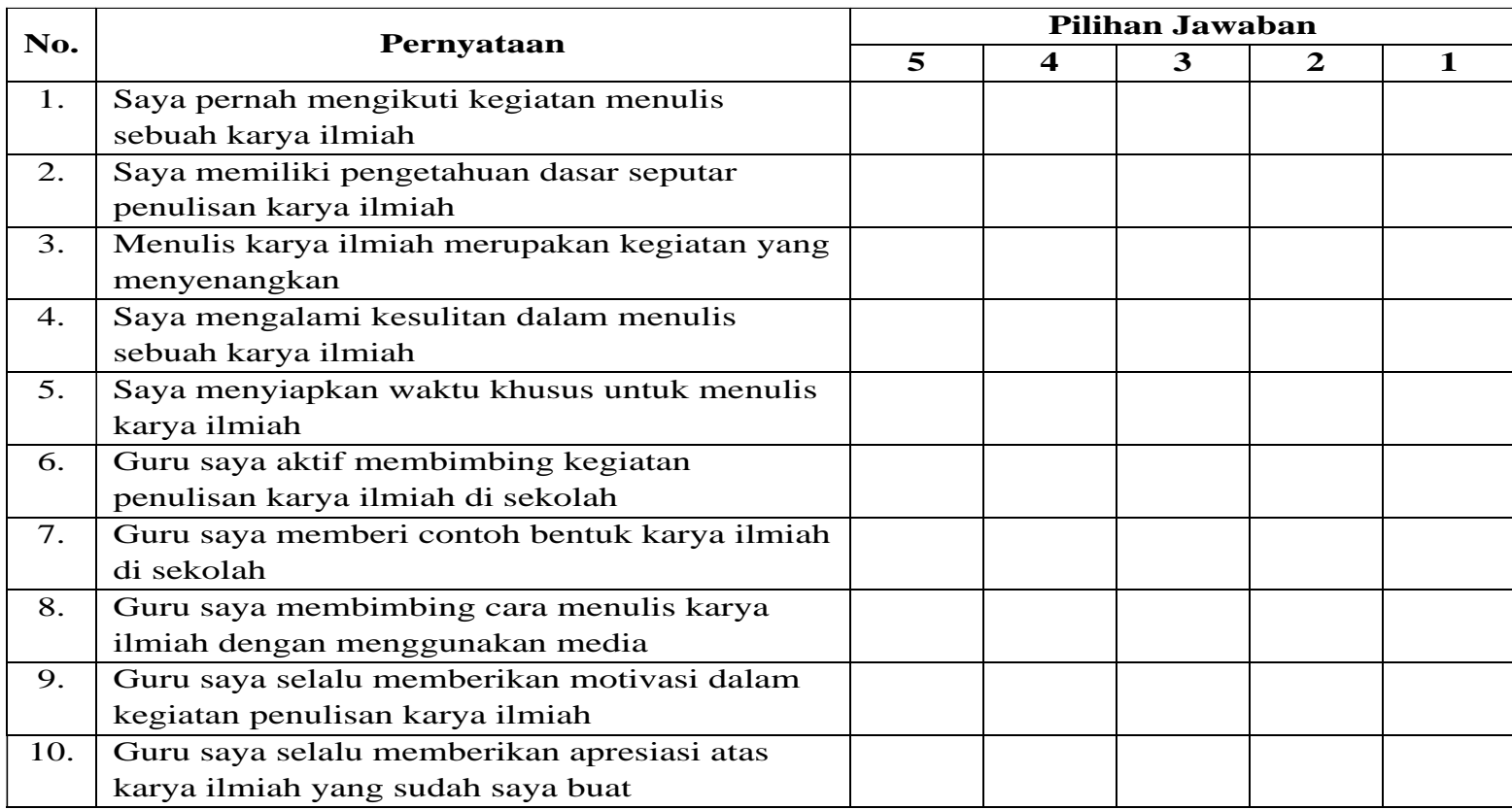

Kuesioner pada Tabel 1 digunakan kembali pada saat post-test. Hal ini dilakukan untuk mengetahui apakah terdapat perbedaan mengenai kemampuan siswa dalam menulis karya ilmiah, respon siswa terhadap pelatihan, dan keterampilan guru dalam melakukan bimbingan.

Pelaksanaan pelatihan teknik penulisan karya ilmiah kepada siswasiswi MAN 2 Kota Probolinggo adalah hari kamis sampai sabtu dengan peserta pelatihan adalah siswa-siswi 
kelas X IPA 6 yang berjumlah 30 terbagi menjadi 6 Kelompok. Kegiatan berjalan dengan lancar dan mendapatkan respon yang sangat baik dari peserta pelatihan. Hal ini tampak pada antusiasme peserta dalam mengikuti proses pelatihan. Terdapat lebih dari 15 siswa mengungkapkan keinginannya untuk terus berusaha agar judul karya ilmiah yang selesai disusun untuk segera dibuat proposal secara lengkap.

Kegiatan pertama pada pelatihan ini adalah pemaparan materi oleh tim pelaksana. Materi yang disampaikan adalah tentang teknik penulisan karya ilmiah, triktrik cepat pencarian informasi yang berkaitan dengan artikel jurnal, buku, makalah, dan sebagainya di internet. Peserta menyimak dengan hikmat dengan sesekali bertanya ketika ada materi yang belum jelas untuk dipahami. Materi yang diberikan merupakan materi baru bagi peserta. Siswa belum pernah belajar tentang karya ilmiah, mulai dari pengertian; langkah-langkah dalam menyusun; dan cara mempublikasikannya.

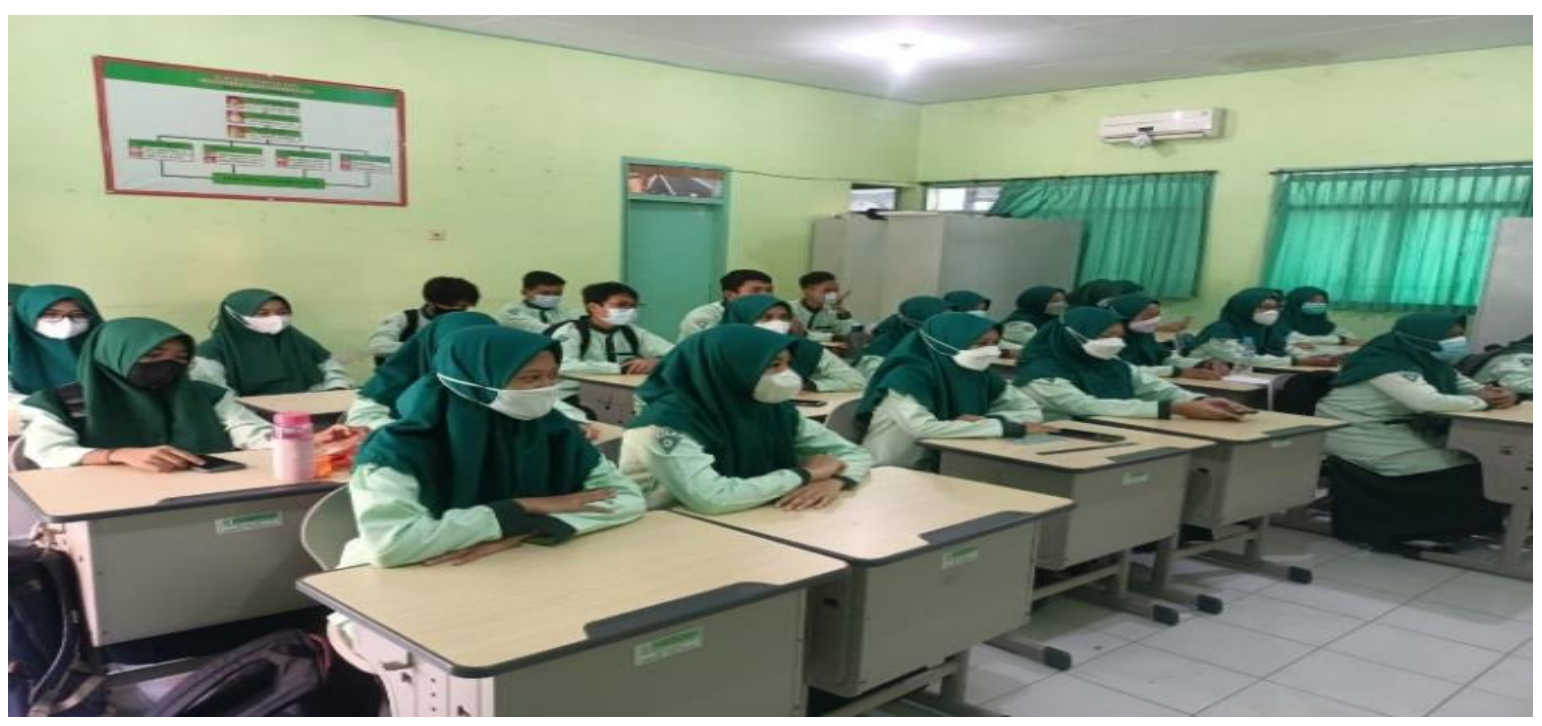

Gambar 1. Kegiatan Pre-test 


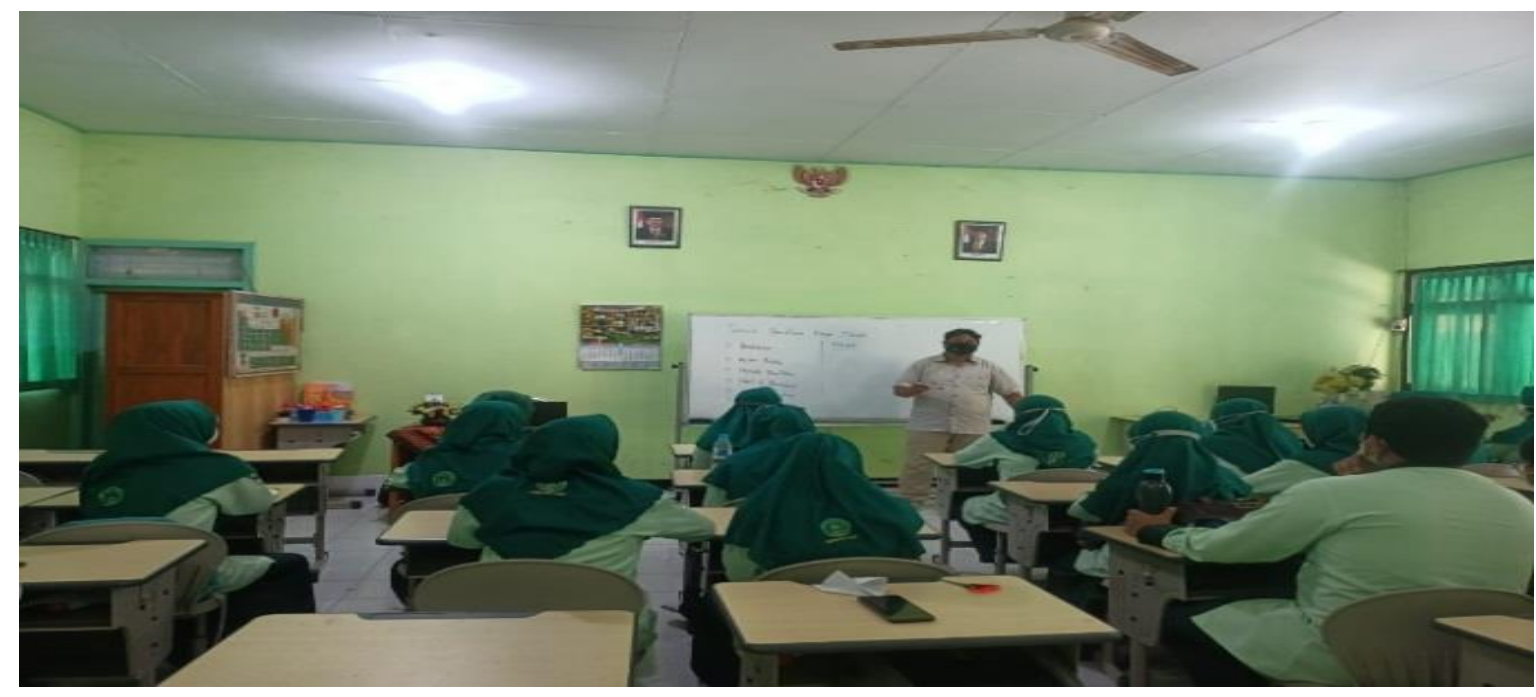

Gambar 2. Pemaparan Materi Pelatihan

Kegiatan kedua adalah praktik menyusun proposal karya ilmiah secara kelompok. Peserta dibagi menjadi 6 kelompok. Setiap kelompok menyusun proposal yang berisi judul, latar belakang masalah, tujuan, manfaat, dan metode penelitian. Kegiatan ini didampingi penuh oleh tim pelaksana. Siswa saling bertukar pendapat dengan teman sekelompok dalam menentukan tiap item proposal. Tugas pendamping adalah memberikan arahan agar proposal yang disusun sesuai dengan ketentuan yang terdapat di materi kegiatan pertama.

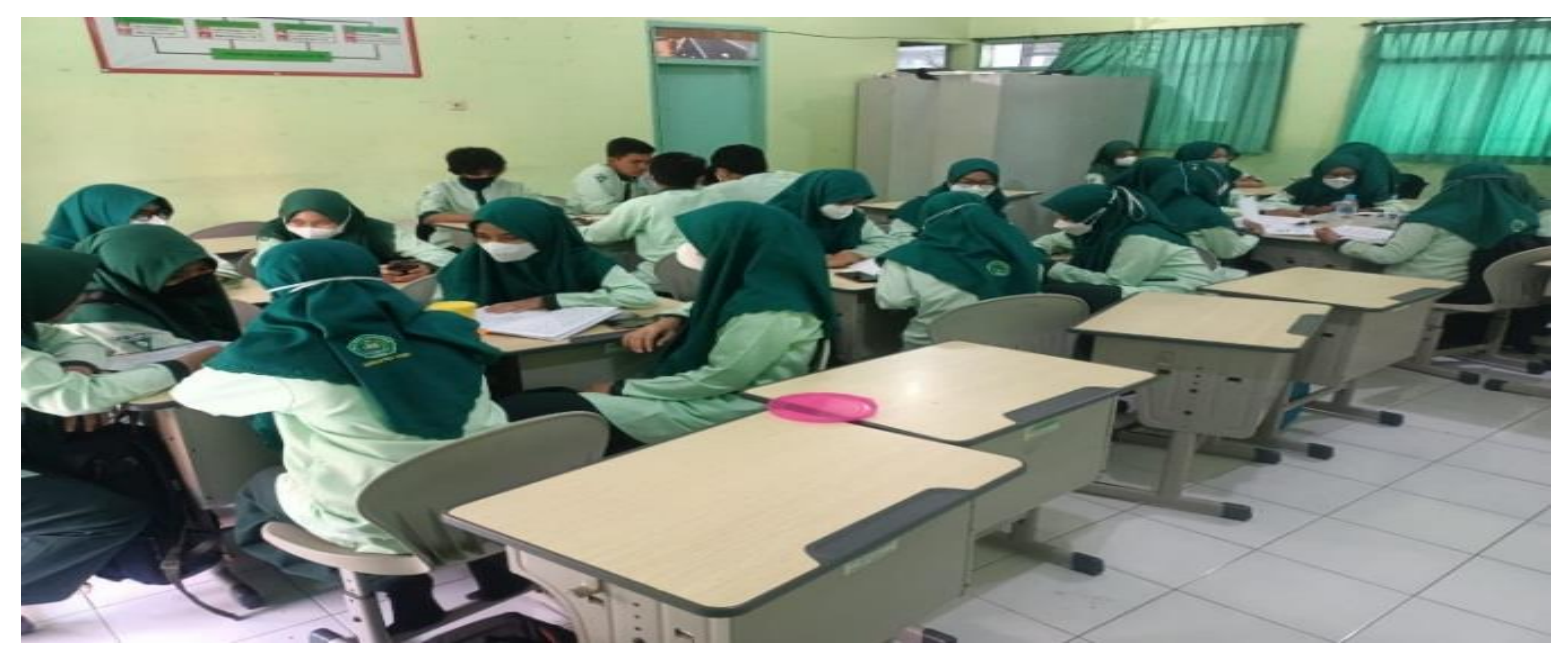

Gambar 3. Peserta Menyusun Proposal 


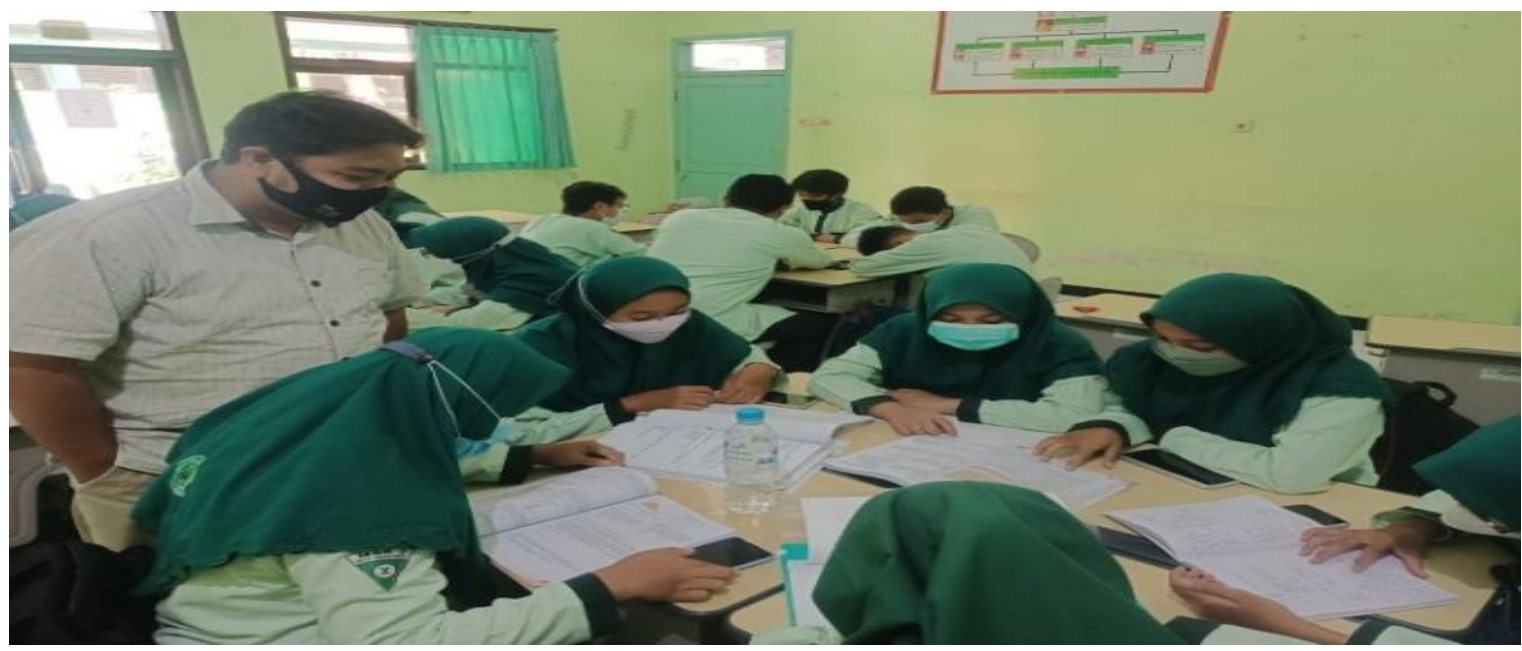

Gambar 4. Mentoring Penyusunan Proposal

Kegiatan ketiga adalah mempresentasikan proposal hasil diskusi dari tiap kelompok. Peserta mempresentasikan di depan kelas. Tim pelaksana menanggapi langsung dan memberikan koreksi jika terdapat kesalahan. Kegiatan tahap ini memberikan motivasi yang besar untuk siswa dalam penyusunan proposal. Terlihat ada 10 siswa yang aktif bertanya ketika teman kelompok lain mempresentasikan proposal dan siswa aktif mencatat hasil koreksi dari tim pelaksana.

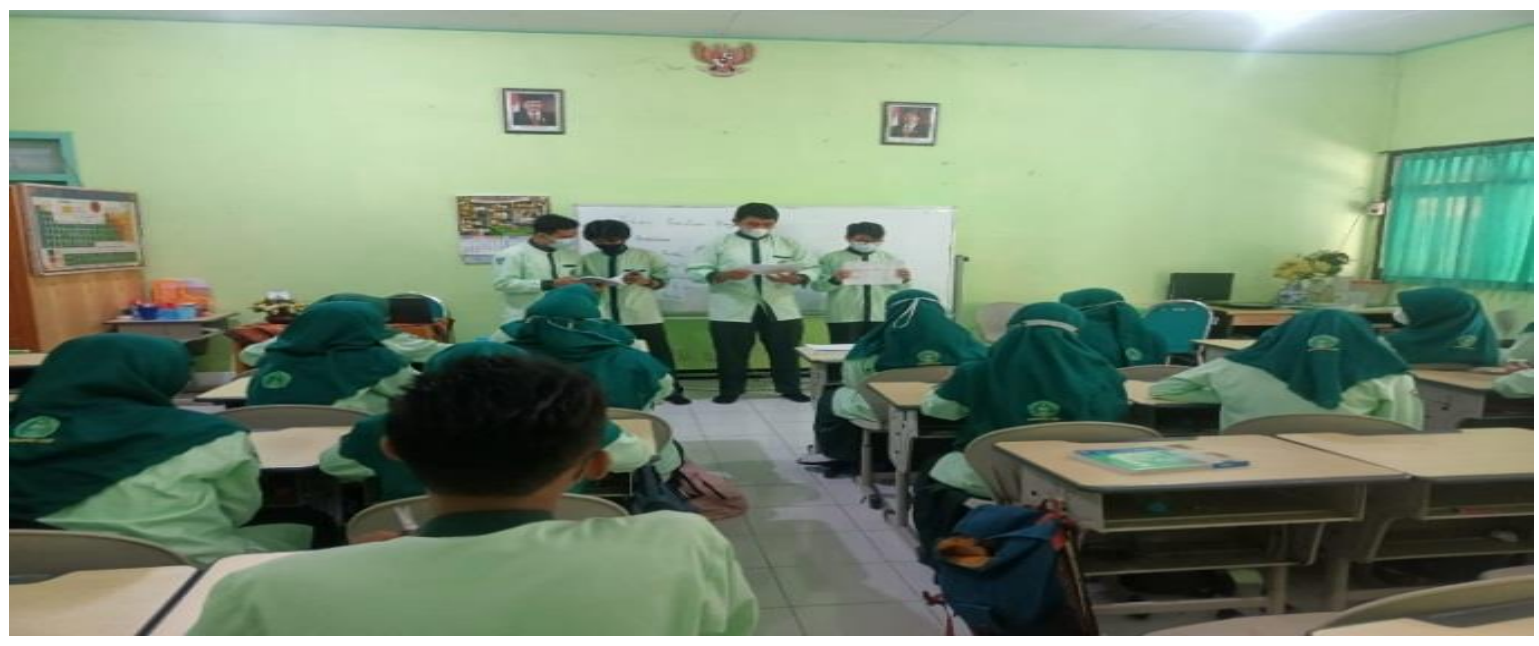

Gambar 5. Kegiatan Presentasi Proposal 


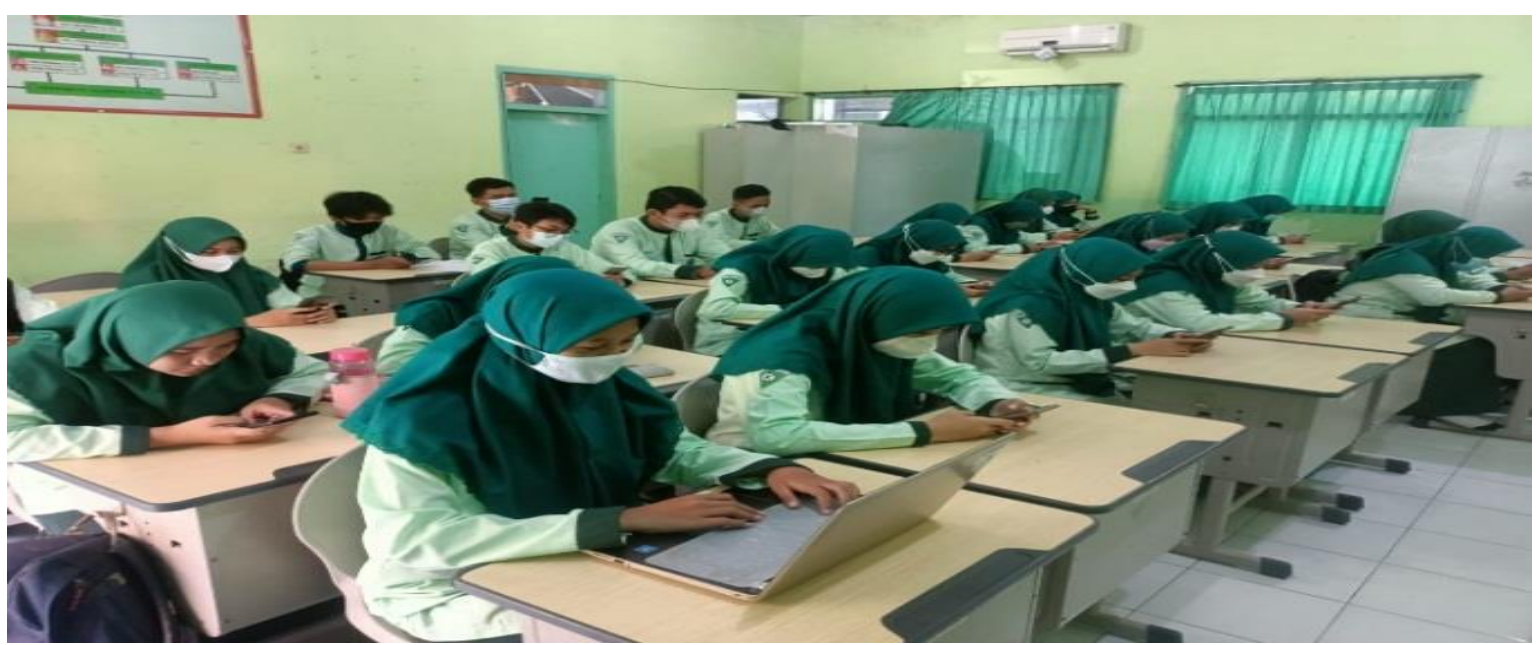

Gambar 6. Kegiatan Post-test

Pada tahap akhir pelaksanaan pelatihan yang telah dilakukan, siswa terlihat sudah paham dalam menyusun sebuah proposal yang meliputi judul, latar belakang masalah, tujuan, manfaat, dan metode penelitian dengan benar. Berikut adalah perbandingan kompetensi siswa-siswi MAN 2 Kota Probolinggo sebelum dan sesudah mengikuti pelatihan teknik penulisan karya ilmiah.

\section{Tabel 1. Perbandingan Kompetensi Peserta Pelatihan}

\begin{tabular}{|c|c|c|c|}
\hline No. & Materi & Sebelum Pelatihan & Setelah Pelatihan \\
\hline 1. & $\begin{array}{l}\text { Teknik menulis } \\
\text { karya ilmiah }\end{array}$ & $\begin{array}{l}\text { a. Judul masih belum menarik } \\
\text { b. Tata bahasa kurang tepat } \\
\text { c. Tata tulis kurang tepat } \\
\text { d. Penulisan daftar Pustaka } \\
\text { kurang tepat }\end{array}$ & $\begin{array}{l}\text { a. Peserta mampu } \\
\text { menentukan judul yang } \\
\text { menarik dan lebih } \\
\text { terarah } \\
\text { b. Peserta mampu } \\
\text { menggunakan bahasa } \\
\text { yang baik } \\
\text { c. Tata tulis sudah baik } \\
\text { d. Peserta mampu menulis } \\
\text { daftar Pustaka dengan } \\
\text { benar }\end{array}$ \\
\hline 2. & Bidang karya ilmiah & $\begin{array}{l}\text { Sebagian besar peserta pelatihan } \\
\text { masih kebingungan dalam } \\
\text { menentukan topik penelitian }\end{array}$ & $\begin{array}{l}\text { Peserta mampu } \\
\text { menentukan topik } \\
\text { penelitian dengan baik }\end{array}$ \\
\hline 3. & $\begin{array}{l}\text { Penggunaan internet } \\
\text { sebagai referensi }\end{array}$ & $\begin{array}{l}\text { Peserta belum maksimal dalam } \\
\text { menggunakan internet sebagai } \\
\text { salah satu referensi penulisan } \\
\text { karya ilmiah }\end{array}$ & $\begin{array}{l}\text { Peserta mampu } \\
\text { menggunakan internet } \\
\text { sebagai salah satu referensi } \\
\text { penulisan karya ilmiah }\end{array}$ \\
\hline
\end{tabular}


1. Saya mampu menjelaskan pengertian dari karya tulis ilmiah

2. Saya mampu menentukan judul karya tulis ilmiah yang menarik

3. Saya mampu menggunakan tata bahasa yang baik dalam menyusun proposal karya ilmiah

4. Saya mampu menggunakan tata tulis yang tepat dalam menyusun proposal karya ilmiah

5. Saya mampu menulis daftar pustaka dengan benar
6. Saya mampu menentukan topik penelitian dengan baik

7. Saya mampu menyusun proposal penelitian

8. Saya mampu mengakses internet dengan baik

9. Saya mampu mencari referensi karya ilmiah melalui buku

10. Saya mampu mencari referensi karya ilmiah secara online

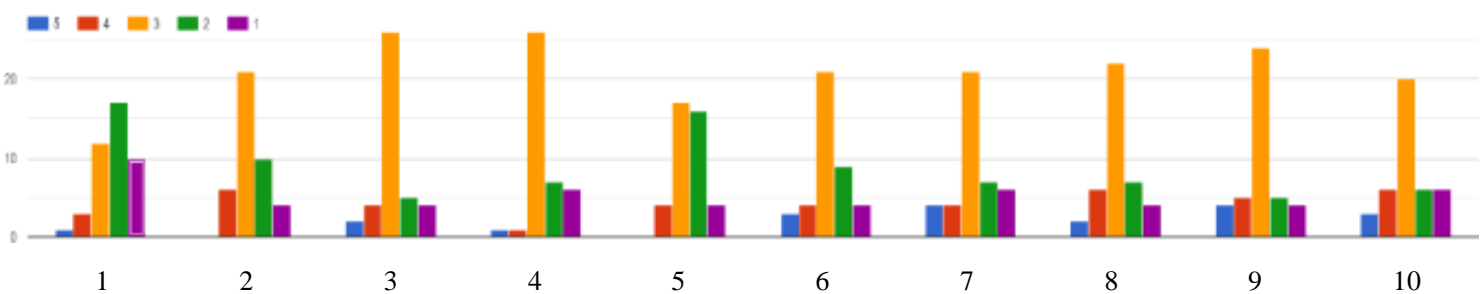

Gambar 7. Hasil pre-test siswa dalam bentuk histogram

Hasil pre-test terlihat pada

Gambar 7 menunjukkan bahwa masih banyak terdapat siswa yang belum pernah mengikuti kegiatan penulisan karya ilmiah. Selain itu ditunjukkan pula bahwa pengetahuan siswa tentang tata cara menulis karya ilmiah sangat kurang dan mengalami kesulitan pada saat penyusunan. Guru di sekolah kurang menunjukkan contoh karya ilmiah dan dalam penyampaiannya tidak menggunakan media, sehingga pengetahuan yang disampaikan kurang dipahami oleh siswa. 


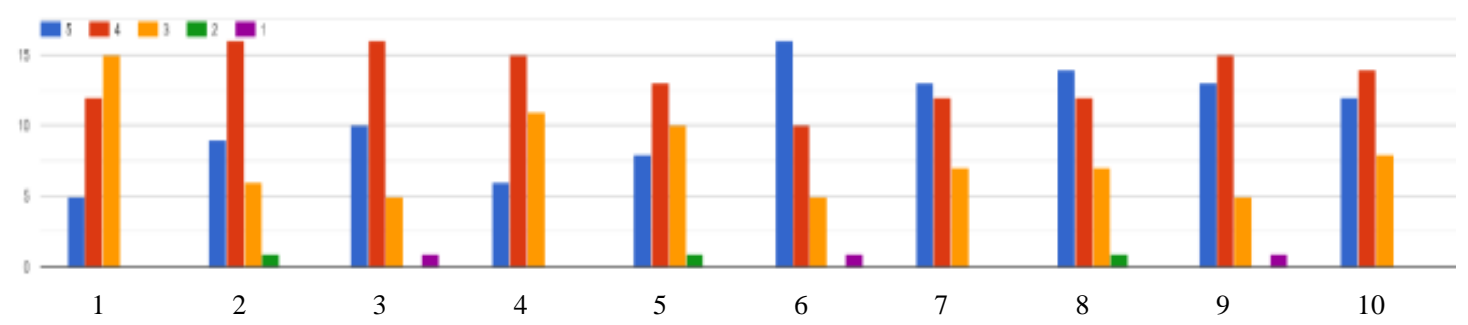

Gambar 8. Hasil post-test siswa dalam bentuk histogram

Hasil post-test terlihat pada Gambar 8 menunjukkan bahwa siswa memberikan respon yang positif setelah mendapatkan pelatihan mengenai teknik penulisan karya ilmiah. Hal ini ditunjukkan bahwa terdapat 16 orang siswa mendapatkan pengetahuan dasar tentang penulisan karya ilmiah setelah mengikuti pelatihan dan menyatakan bahwa menulis karya ilmiah adalah hal yang menyenangkan. Selain itu, terdapat perubahan yang nyata pada keterampilan siswa dalam menulis karya ilmiah. Beberapa siswa tampak tidak mengalami kesulitan dalam menulis karya ilmiah setelah pelatihan dan siswa meluangkan waktu khusus untuk belajar menulis karya ilmiah. Peningkatan yang terjadi ini dapat dikembangkan oleh guru dengan melakukan pembinaan yang teratur agar dapat melatih keterampilan siswa untuk meningkatkan kemampuan menulisnya.

Hasil penelitian ini relevan dengan penelitian yang dilakukan oleh Ismillah (2020) yang menyatakan bahwa peserta pelatihan telah mengikuti kegiatan dengan sangat baik. Hal ini ditunjukkan dengan antusiame dan peningkatan pemahaman peserta terkait tentang penulisan karya ilmiah yang baik. Selain itu, hasil penelitian ini juga relevan dengan penelitian yang dilakukan oleh Nora (2017) yang menyatakan bahwa dengan adanya kegiatan pelatihan penulisan karya ilmiah remaja dapat mengubah cara pandang siswa dalam membuat karya ilmiah. Hal ini menyebabkan meningkatnya rasa percaya diri siswa 
dalam menulis karya ilmiah remaja untuk mengikuti lomba-lomba KIR.

\section{SIMPULAN}

Kesimpulan dari kegiatan untuk penulisan karya ilmiah ini adalah:

1. Pelaksanaan pelatihan teknik penulisan karya ilmiah sangat berdampak positif bagi siswa-siswi MAN 2 kota Probolinggo, terlihat bahwa kompetensi siswa meningkat setelah dilaksanakan pelatihan, yang meliputi: teknik menulis; cakupan bidang; dan penggunaan internet sebagasi referensi karya ilmiah.

2. Penyampaian materi tentang teknik penulisan karya ilmiah dapat meningkatkan pengetahuan siswa agar lebih kreatif dalam berpikir untuk menemukan ide dan gagasan yang dapat dijadikan sebagai topik untuk membuat tulisan karya ilmiah.

3. Kegiatan yang dilakukan oleh tim pelaksana merupakan sebuah kegiatan positif yang bertujuan untuk membekali para siswa dalam bidang karya ilmiah yang dapat menjadi bekal bagi mereka di kemudian hari, misalkan dalam membuat laporan-laporan kerja praktek maupun sebagai bekal pada saat mereka melanjutkan ke jenjang perkuliahan.

Berdasarkan hasil simpulan di atas, untuk kegiatan selanjutnya dapat dilakukan dengan monitoring dan evaluasi hasil karya ilmiah di MAN 2 Kota Probolinggo menuju Lomba Karya Ilmiah tingkat nasional ataupun internasional.

\section{UCAPAN TERIMAKASIH}

Terima kasih kepada Kepala MAN 2 Kota Probolinggo atas nama Drs. Moh Alfan Makmur, M.M. telah memfasilitasi kegiatan pelatihan ini dan waka kurikulum Siti Musrifa, S.Pd. yang menjembatani terlaksananya kegiatan pelatihan teknik penulisan karya ilmiah ini. 


\section{REFERENSI}

Yusuf, M. (2017). Metode Penelitian Kuantitatif, Kualitatif, \& Penelitian gabungan. Jakarta: PT Fajar Interpratama Mandiri.

Hardani, dkk. (2020). Metode Penelitian Kualitatif \& Kuantitatif. Yogyakarta: CV. Pustaka Ilmu.

Purnamasari, I., Nor Hayati M., dan Yuniarti, I. 2020. Pelatihan Penulisan Karya Tulis Ilmiah Untuk Mendorong Peningkatan Kualitas Siswa Tingkat SMA. Aksiologiya. Vol 4, No.2.

Kurniawati, D., Agustini SM, V., Ariyani, V. 2018. Pelatihan Pembuatan Karya Ilmiah Remaja Bagi Siswa-Siswi SMAN 6 dan MAN 2 Kota Madiun. Warta Abdimas No. 01 Tahun 1/Juni 2018.

Semi, A. (2007). Dasar-dasar Keterampilan Menulis. Bandung: Angkasa.

Arifin, Z. 2008. Metodelogi Penelitan Pendidikan, Surabaya : Lentera Cendikia.

Pelatihan Karya Tulis Ilmiah Bagi Siswa-Siswi SMAN 9 Balikpapan. (https://itk.ac.id/pelatihankarya-tulis-ilmiah-bagi-siswasiswi-sman-9-balikpapan/, diakses tanggal 16 Desember 2020)

Shadiqi, M.A. 2019. Memahami dan Mencegah Perilaku Plagiarisme dalam Menulis Karya Ilmiah, Buletin Psikologi, vol 27, no 1, hal 30-42.

Ismillah, N., dkk. 2020. Pelatihan Penulisan Karya Ilmiah Bagi Siswa SMA Negeri 1 Selong Kabupaten Lombok Timur NTB. Prosiding PEPADU LPPM Universitas Mataram. Vol.2.

Nora, A. 2017. Pelatihan Penulisan Karya Tulis Ilmiah Remajadi SMAN 101 Jakarata Barat. Jurnal Abdimas Volume 3 Nomor 2. 